\title{
SCIDiC
}

International Journal of Dentistry and Oral Science (IJDOS)

ISSN: 2377-8075

\section{The Effectiveness Of Laser Radiation On Curved Root Canals: A Review Study}

\section{Research Article}

Farshad Khosraviani ${ }^{1 *}$, Mojgan Danyal Khosravi², Tara Azimi ${ }^{3}$

${ }^{1}$ D.D.S, University of California Los Angeles, School of Dentistry, California, USA.

${ }^{2}$ Student Doctor, Arizona School of dentistry\& Oral Health, Arizona, USA.

${ }^{3}$ D.D.S, Shahid Beheshti University of Medical Sciences, School of Dentistry, Tehran, Iran.

Abstract

Introduction: Laser has an effective role in endodontic treatment. Most studies have examined the effects of laser radiation on straight canals. The aim of this study was to review the therapeutic effect of laser radiation on curved root canals.

Methods: First, the related keywords were searched in four databases: Scopus, PubMed, WOS and Google Scholar. After merging the collected titles, original eligible articles published by the end of February 2021 were scrutinized.

Results: Out of 16 collected titles, 10 articles met the study criteria. The lasers used included Er, Cr: YSGG $(2780 \mathrm{~nm}), \mathrm{Nd}$ : YAG $(1064 \mathrm{~nm})$, Er: YAG $(2940 \mathrm{~nm})$ and diode $(660,940,980 \mathrm{~nm})$. The canal curvature in 6 studies was between 5-33․ Also, the degree of curvature was described $>20^{\circ}$ in three studies, and in one study it was $31 \pm 9^{\circ}$. Therapeutic goals of laser irradiation included root canal shaping, smear layer removal, anti-enterococcus faecalis and anti-candida albicans effect, levels of filler and sealer penetration into dentin tubules. The results of the studies showed that the laser radiation was not effective for curved root canal shaping; however, it was effective on other mentioned purposes compared to the control group.

Conclusion: Radiation of the above lasers in curved canals, despite the weakness in canal shaping, can be effective as an adjuvant tool for canal cleaning, disinfecting and sealing improvement.

Keywords: Laser; Curved Canal; Endodontics; Root Canal; Review.

\section{Introduction}

Proper shaping, cleaning and disinfecting and then achieving a strong seal by obstructing the root canal system are essential steps of a successful endodontic treatment [1].

The anatomical features of the root canal affect the success of its treatment. Curved canals create constraints for proper biomechanical preparation and sealing $[2,3]$. These constraints are more pronounced for canals with sever curvature $[4,5]$. Fractures of endodontic instruments, perforation, filling defects, buildup of elbow or zip, failing to achieve the working length and defect in debris removal are some of these constraints [4, 5] which lead to infection, relapse of symptoms, and sometimes a re-treatment [6]. Depending on the type of curvature measurement methods, a varied prevalence of curved canals has been reported in studies. Generally, this prevalence varies between 5 to $95 \%$ [7-9].
The use of manual steel files has a significant weakness in the preparation of curved canals and in some cases the desired canal shape and debris removal are achieved less than is expected [10, 11]. Although, Ni-Ti manual files have reduced the problems of steel manual files, but they have not completely eliminated the disadvantages of steel manual files [12]. Rotary instruments are more effective than manual ones in preparing the curved canal. Rotary instruments, by reducing the canal preparation time, reducing the possibility of entrapment and fracture of the instrument inside the canal, and preparing the canal with the optimal radius, provide an easier and safer process for the dentist [12-14]. However, rotary instruments are not completely effective in removing debris from the root canal, and the use of adjuvant modalities may provide a more appropriate treatment in their biomechanical preparation.

Laser radiation has found various applications in endodontic treatment. Antibacterial effects, canal shaping, smear layer removal, irritants activation and canal sealing are some of its advantages

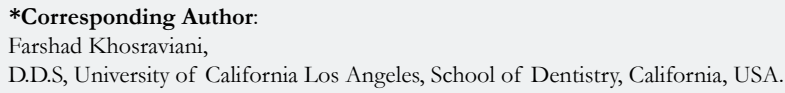

Citation: Farshad Khosraviani, Mojgan Danyal Khosravi, Tara Azimi. The Effectiveness Of Laser Radiation On Curved Root Canals: A Review Study. Int J Dentistry Oral Sci. 2021;8(11):5168-5174. doi: http://dx.doi.org/10.19070/2377-8075-210001038

Copyright: Farshad Khosraviani ${ }^{\circ} 2021$. This is an open-access article distributed under the terms of the Creative Commons Attribution License, which permits unrestricted use, distribution and reproduction in any medium, provided the original author and source are credited. 
in endodontic treatment [15-19]. In addition, unlike conventional irritants such as EDTA, laser does not result in an allergic reaction and may be a good alternative choice for people who are allergic to these substances $[20,21]$. The effects of laser during endodontic treatment depend on the type of laser, radiation setting and canal morphology, and changes in any of these items can change the treatment outcome [22].

Most studies have evaluated the effect of lasers on direct canals and fewer findings are available on the use of lasers on curved canals $[23,24]$. The aim of this review was to evaluate the effectiveness of laser irradiation on the treatment of curved root canals. The results of this study can provide a summary of the available evidence in this regard.

\section{Methods}

First, the following keywords and phrases were extracted using $\mathrm{MeSH}$ and related articles. These were then searched in three databases: Scopus, PubMed, and WOS.

(laser OR "laser radiation" OR "photodynamic therapy" OR "light therapy") AND ("curved root canal" OR "root canal curvature") The collected titles in the above databases were limited to original articles published by the end of February 2021. The titles were then combined electronically with Mendeley desktop software (ver 1.19) to remove duplicates. Also, to increase the search scope, the keywords were searched in the Google Scholar database, and the 200 initial titles displayed were checked and non-duplicate related titles were added to the search results.

Titles were submitted electronically to two reviewers (A.A \& B.B) to select eligible articles. If there were no consensus between the two reviewers on some of the titles, the third reviewer (C.C) would decide on them.

Inclusion criteria included original articles, laser radiation, use of root canals with a curvature of at least $5^{\circ}$, and in-vivo and ex-vivo studies. Exclusion criteria included non-English language articles, lack of access to the full text of articles, case report studies, studies without control groups, and deficiencies in methodology or result reporting.
Eligible articles were thoroughly examined by the third reviewer and the results were extracted. Necessary information was extracted from the articles including the type of study, the type of tooth, the amount of canal curvature, the type of laser and its radiation conditions, the therapeutic goals of laser radiation and its effectiveness results. The effectiveness of the laser was reported as effective (E) where a significant difference was observed with the negative control group or where there was not a significant difference in the positive control group, and was reported as ineffective(I) if there was no significant difference in the negative control group.

CONSORT 2010 Checklist was used to assess the quality of the clinical trial studies 17. This checklist consists of 37 items. The number of items obtained by each article is divided into total items and expressed as a percentage. Cochrane Collaboration's tool was used for assessing the risk of bias in the clinical trial studies 18. Risk of bias was described as high $(\mathrm{H})$, low $(\mathrm{L})$, and unknown $(\mathrm{U})$. To the best of our knowledge, there was not a qualified checklist to assess the quality and risk of bias in laboratory studies. However, the use of inclusion and exclusion criteria in selecting the articles could have greatly reduced the risk of bias in this study.

\section{Results}

\section{Search Results}

Figure 1 shows a summary of the article selection process. 22 titles were found in three databases: Scopus, PubMed, and WOS. 22 titles were found, leaving 12 titles after deleting duplicate titles. Four non-duplicate titles were also found on the Google Scholar database. In the initial evaluation, 3 articles out of 16 titles were excluded from the study the reasons for which are given in Figure 1. Out of the remaining 13 titles, one study was excluded due to the use of resin block model to simulate the root canal, one study due to the evaluation of thermal changes of laser radiation (nontherapeutic intervention) and one study due to lack of access to its full text. At the end, ten articles were thoroughly reviewed. Table 1 shows a summary of the final ten articles.

\section{Type of studies}

Figure 1. Article selection process.

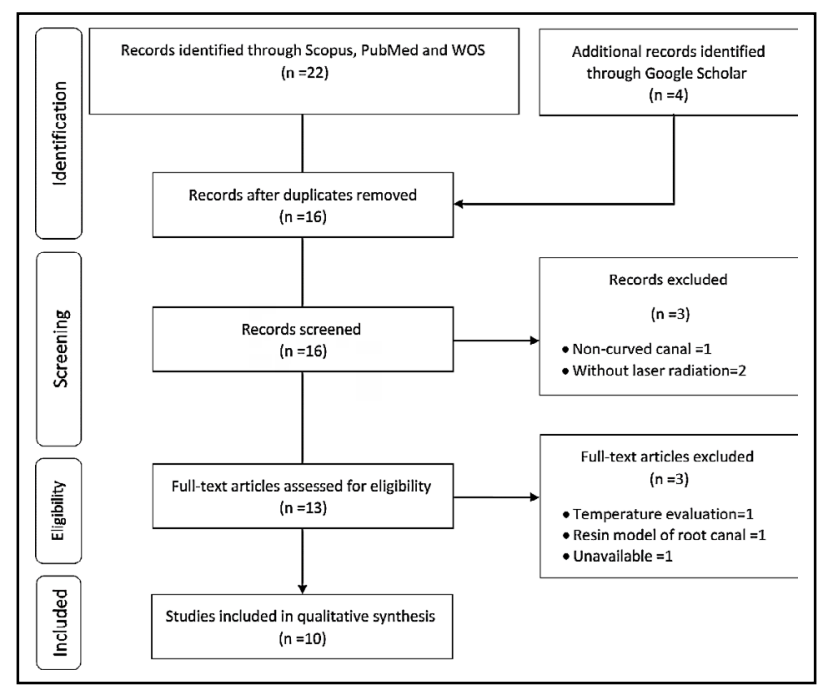


Table 1. A summary of the final articles. Abbreviations: $a . I=$ ineffective $, b, E=$ effective, $(+)=$ dual wavelength radiation, $d$, PDT=photodynamic theraphy.

\begin{tabular}{|c|c|c|c|c|c|c|c|c|c|}
\hline Reference & $\begin{array}{c}\text { type of } \\
\text { study }\end{array}$ & Laser & $\begin{array}{c}\text { Radiation } \\
\text { energy }(\mathrm{J}-\mathrm{mJ})\end{array}$ & $\begin{array}{l}\text { Radiation } \\
\text { power (w) }\end{array}$ & $\begin{array}{c}\text { Fiber tip diam- } \\
\text { eter }(\mathrm{m} \mu)\end{array}$ & $\begin{array}{l}\text { Canal cur- } \\
\text { vature }\left({ }^{\circ}\right)\end{array}$ & $\begin{array}{c}\text { Type of treat- } \\
\text { ment }\end{array}$ & $\begin{array}{c}\text { Effec- } \\
\text { tiveness }\end{array}$ & Results \\
\hline $\begin{array}{c}\text { Matsuoka et } \\
\text { al. (25) }\end{array}$ & Ex- vivo & Er,Cr:YSGG & - & 2 & $\begin{array}{l}200 \\
320\end{array}$ & 10,15 & $\begin{array}{l}\text { Shaping Smear } \\
\text { layer removal }\end{array}$ & $\mathrm{Ia}, \mathrm{Eb}$ & $\begin{array}{l}\text { The laser is suitable for } \\
\text { the smear layer removal } \\
\text { and canal shaping with a } \\
\text { curvature }<10^{\circ} \text {. }\end{array}$ \\
\hline $\begin{array}{c}\text { Jahan et al. } \\
\text { (26) }\end{array}$ & Ex- vivo & Er,Cr:YSGG & - & 2 & $\begin{array}{l}200 \\
320 \\
400\end{array}$ & $\begin{array}{l}0-5 \\
>5\end{array}$ & $\begin{array}{l}\text { Shaping Smear } \\
\text { layer removal }\end{array}$ & $\mathrm{I}, \mathrm{E}$ & $\begin{array}{c}\text { The laser has less effect } \\
\text { on the curved canal shap- } \\
\text { ing than the direct canal } \\
\text { and has a suitable effect } \\
\text { on the smear layer } \\
\text { removal. }\end{array}$ \\
\hline $\begin{array}{c}\text { Yasuda et al. } \\
(27)\end{array}$ & Ex- vivo & $\begin{array}{l}\text { Er:YAG } \\
\text { Nd:YAG }\end{array}$ & $\begin{array}{c}50 \mathrm{mj} \\
100 \mathrm{mj}\end{array}$ & $\begin{array}{c}0.5 \\
1\end{array}$ & R300T 200 & $\begin{array}{c}0-5 \\
5-10\end{array}$ & Anti- bacterial & $\mathrm{E}$ & $\begin{array}{l}\text { The bacteriocidal effect } \\
\text { of the laser is } \\
\text { weaker for the curved } \\
\text { canal. }\end{array}$ \\
\hline $\begin{array}{l}\text { Moon et al. } \\
\text { (28) }\end{array}$ & Ex- vivo & Nd:YAG & $150 \mathrm{mj}$ & 1.5 & 200 & $>20$ & $\begin{array}{l}\text { Sealer penetra- } \\
\text { tion }\end{array}$ & $\mathrm{E}$ & $\begin{array}{l}\text { Activation of } \mathrm{NaOCl} \\
\text { rather than EDTA } \\
\text { increases the penetration } \\
\text { of gutta-percha } \\
\text { into the dentin tubules. }\end{array}$ \\
\hline $\begin{array}{l}\text { Sabari Murug- } \\
\text { esun et al. (29) }\end{array}$ & Ex- vivo & Er,Cr:YSGG & $62.5 \mathrm{mj}$ & 1.25 & 300 & $15-30$ & $\begin{array}{l}\text { Smear layer } \\
\text { removal }\end{array}$ & $\mathrm{E}$ & $\begin{array}{l}\text { The use of conical fiber } \\
\text { tip, especially with EDTA } \\
\text { activation, has a better } \\
\text { effect on smear layer } \\
\text { removal. }\end{array}$ \\
\hline $\begin{array}{c}\text { Sabino et al. } \\
\text { (30) }\end{array}$ & Ex- vivo & $\begin{array}{l}\text { Diode, } 660 \\
\mathrm{~nm}(\text { PDTd })\end{array}$ & $36 j$ & 0.1 & $\begin{array}{l}0.3-1 \\
(\mathrm{~mm})\end{array}$ & $15-25$ & Anti-fungal & $\mathrm{E}$ & $\begin{array}{c}\text { The use of conical fiber } \\
\text { tip has a better effect } \\
\text { on reducing Candida } \\
\text { albicans } \\
\text { colony. }\end{array}$ \\
\hline $\begin{array}{l}\text { Abdelga- } \\
\operatorname{wad}(31)\end{array}$ & Ex- vivo & Diode, $980 \mathrm{~nm}$ & - & 2 & 320 & $>20$ & Canal occlusion & $\mathrm{E}$ & $\begin{array}{c}\text { Laser in combina- } \\
\text { tion with gutta-core } \\
\text { instrument creates } \\
\text { better obstruction than } \\
\text { single-cone instrument } \\
\text { without } \\
\text { laser irradiation on sealer } \\
\text { penetration. }\end{array}$ \\
\hline $\begin{array}{c}\text { Ballout et al. } \\
\text { (32) }\end{array}$ & $\begin{array}{l}\text { Ex- } \\
\text { vivo }\end{array}$ & $\begin{array}{l}\text { Diode, } 660 \\
\text { nm(PDT) }\end{array}$ & - & 0.4 & - & $28-33$ & $\begin{array}{c}\text { Anti- } \\
\text { bacterial }\end{array}$ & I & $\begin{array}{l}\text { Unlike } \mathrm{NaOCl}, \mathrm{PDT} \\
\text { has no } \\
\text { antibacterial effect. }\end{array}$ \\
\hline $\begin{array}{c}\text { Gupta et al. } \\
\text { (33) }\end{array}$ & Ex- vivo & $\begin{array}{l}\text { Er:YAG } \\
\text { Nd:YAG }\end{array}$ & $25 \mathrm{~mJ}$ & $\begin{array}{l}1 \\
1\end{array}$ & $\begin{array}{l}600 \\
320\end{array}$ & $>20$ & $\begin{array}{l}\text { Smear layer } \\
\text { removal }\end{array}$ & $\mathrm{E}$ & $\begin{array}{l}\text { Er: YAG laser is more } \\
\text { effective on smear layer } \\
\text { removal and sealer } \\
\text { penetration. }\end{array}$ \\
\hline $\begin{array}{l}\text { Nasher et al. } \\
\text { (34) }\end{array}$ & Ex- vivo & $\begin{array}{c}\text { Er,Cr:YSGG+c } \\
\text { Diode,940nm }\end{array}$ & - & $\begin{array}{c}1.25,2 \\
2\end{array}$ & RFT2 RFT2 & $31 \pm 9$ & $\begin{array}{l}\text { Smear layer } \\
\text { removal }\end{array}$ & $\mathrm{E}$ & $\begin{array}{l}\text { Using } 2 \mathrm{w} \text { of power } \\
\text { for Er, Cr: YSGG laser } \\
\text { is more effective for } \\
\text { removing the } \\
\text { smear layer. }\end{array}$ \\
\hline
\end{tabular}

All studies were performed on extracted human teeth in the laboratory.

\section{Laser and radiation conditions}

In studies lasers of $2780 \mathrm{~nm}$ Er, Cr: YSGG, [25, 26, 29, 34], 2940 nm Er: YAG [27, 33], 1064 nm Nd: YAG [27, 28, 33], and diodes of $660 \mathrm{~nm}[30,32], 940 \mathrm{~nm}[34]$ and $980 \mathrm{~nm}$ [31] were used. One study used a combination of Er, Cr: YSGG - Diode lasers [34]. In two studies, the diode laser was irradiated in the form of photodynamic therapy (PDT) $[30,32]$. Only five studies reported laser radiation energy, which ranged from 25 to $150 \mathrm{~mJ}$ [27-29, 33] for Er: YAG, Er, Cr: YSGG, and Nd: YAG lasers and $36 \mathrm{~J}$ for diode lasers [30]. The range of radiation power in the studies varied from 0.1 to $2 \mathrm{w}$.

Studies used specific laser endodontic fiber. In general, the fibers were moved in upward- downward motion inside the canal.
The fiber diameters in the studies were 200, 300, 320, 400, 600 micrometers. In one study, the diode laser fiber ranged from 0.3 to $1 \mathrm{~mm}$ in diameter from base to tip [30].

\section{Canal curvature}

In one classification, the curvature of the evaluated canals was 5 to $15^{\circ}$ in three studies [25-27], and 15 to $33^{\circ}$ in three other studies [29, 30, 32]. Also, three studies in their report used canals with a curvature of more than $20^{\circ}[28,31,33]$ and one study used canals with an average curvature of $31 \pm 9^{\circ}$ [34]. Six studies determined the curvature of the canal with the Schneider method and in other studies the method of measuring the curvature was not mentioned [25, 32-34].

\section{Endodontic treatment models}

Canal shaping in two studies [25, 26], smear layer removal in five 
studies [25, 26, 29, 33, 34], antibacterial effects using Enterococcus faecalis in two studies $[27,32]$, sealer penetration into dentin tubules in two studies [28, 33], canal occlusion in one study [31] and anti- Candida albicans effect in one study [30] were the subjects of the studies.

\section{Effectiveness}

Laser radiation in nine studies in comparison to the negative control group or the positive control group had effective and significant therapeutic results, generally. In addition, in two studies laser irradiation was effective for smear layer removal and was ineffective for canal shaping $[25,26]$. In one study, diode laser radiation in the form of PDT did not show the appropriate antibacterial effect compared to $\mathrm{NaOCl}$ [32]. Below is a summary of the main results of the reviewed studies.

\section{Canal shaping}

Matsuka et al., in order to prepare root canals using Er, Cr: YSGG laser, divided 20 mandibular incisor teeth into 10 and 15 degree curvature groups. Canal preparation was done using laser irradiation and air and water spray. First the $200 \mu \mathrm{m}$ and then the $320 \mu \mathrm{m}$ fiber entered the canal and then irradiation was done. In stereoscope and SEM images, the laser in the $10^{\circ}$ curvature group produced superficial surface roughness without carbonization or melting. In the $15^{\circ}$ curvature group, carbonization, longer irradiation time, perforation and pseudo-canal formation were observed. Such problems were fewer with the $200 \mu \mathrm{m}$ fiber compared with the $320 \mu \mathrm{m}$ one. Also, in the curvature group of $15^{\circ}$, in order to reach the working length, the $320 \mu \mathrm{m}$ fiber had been broken in some cases [25].

Jahan et al., Considering the degree of curvature greater than 5 ${ }^{\circ}$ as a curved canal, and a curvature less than or equal to $5^{\circ}$ as a direct canal, divided 40 molars into two groups of 20 performed two types of preparatory interventions. The first group experienced Er, Cr: YSGG laser irradiation without the use of an irrigant, and the second group canal preparation with $\mathrm{K}$ files with $5.25 \% \mathrm{NaOCl}$ and $3 \% \mathrm{H}_{2} \mathrm{O}_{2}$. Irradiation setting included a power of $2 \mathrm{w}$, a frequency of $20 \mathrm{~Hz}$ and 200, 320 and 400 micrometer fibers for the apical, middle and coronal areas. In the stereoscope and SEM images, the error rate including hyper-instrumentation and edge and pseudo-canal creation was more observed in the laser group. The success rate of reaching the working length in the direct canal in the laser and control group was $100 \%$, and in the curved canals in the distal regions these rates were $62.5 \%$ and $71.4 \%$ in the laser and control groups respectively, which were not significantly different from each other. [26].

\section{Smear layer removal}

Nasher et al. investigated the simultaneous irradiation of two Er, Cr: YSGG-diode $940 \mathrm{~nm}$ lasers in smear layer removal in cannals with an average curvature of $31 \pm 9^{\circ}$. After preparing the canal with a rotary instrument, the canals were divided into five groups: 1. Negative control group in which canals were only rinsed by tap water, 2. Positive control group (17\% EDTA and a final rinse of $3 \% \mathrm{NaOCl}$ ), 3. Conventional group (with XP Endoshaper and finisher with 17\%EDTA), 4. Dual laser radiation of Er, Cr: YSGG (1.25 W) and diode $940 \mathrm{~nm}(2 \mathrm{~W})$ and 5. Dual laser radiation group of Er, Cr: YSGG (2 W) and diode $940 \mathrm{~nm}(2 \mathrm{~W})$.
In microscopic laser scan images, all interventions removed the smear layer significantly compared to the control group. The laser group had better and more significant results than the positive control group but had not any significant differences with the conventional group. The fifth group produced the best result. Also, group five showed a significantly better performance than group four. In group four of Er, Cr: YSGG laser with 1.25 $\mathrm{w}$ power, complete smear layer removal was observed in cervical and middle areas, but in apical areas, smear layer removal was poor. In their other findings, the use of an intracanal entry cycle in the fifth group compared to the four entry cycles in group four provided protection against laser fiber breakage [34].

Sabari Murugesun et al., evaluated the effect of flat and conical fiber tip on smear layer removal from the root canal of mandibular premolars with a curvature of 15 to $30^{\circ}$. They first prepared 81 canals with rotary files and devided them in three groups of 27 of $17 \%$ EDTA, $3 \% \mathrm{NaOCl}$, and $\mathrm{CHX}$. Each group was divided into three subgroups of 9 , including without laser irradiation, and Er, Cr: YSGG laser irradiation with flat and conical tip. The laser was irradiated on the irrigants for 5 seconds. In the findings, by examining the apical third region using SEM images, the subgroups without laser irradiation did not differ from each other in the amount of smear layer removal and there remained significant amounts of debris. The group without laser radiation was not significantly different from the laser group with smooth tip fiber. In the group of lasers with conical tip, 17\% EDTA had a better performance than the other two irrigants of CHX and NAOCL. In comparing the conical tip group with the control group and the flat type group, smear layer removal with the help of EDTA17\% activation showed the best results [29].

In other findings by Matsouka et al., Er, Cr: YSGG laser irradiation in the $10^{\circ}$ curvature group, smear layer was well removed. Also, in the $15^{\circ}$ curvature group, smear layer removal was significant, but in the apical areas, smear layer removal was poor [25].

In the study of Jahan et al. smear layer removal was almost complete in the Er, Cr: YSGG laser group, but in the control group $\left(5.25 \% \mathrm{NaOCl}\right.$ and $\left.3 \% \mathrm{H}_{2} \mathrm{O}_{2}\right)$ the presence of the smear layer was significant [26].

\section{Anti-bacterial and anti-Candida albicans effects}

Yasuda et al. divided 60 straight single root teeth $\left(0-5^{\circ}\right)$ and curved canals $\left(5-10^{\circ}\right)$ in five groups of control (without treatment), $5.25 \% \mathrm{NaOCl}, \mathrm{Nd}$ : YAG laser $(0.5 \mathrm{w}$ and $50 \mathrm{~mJ}-1 \mathrm{w}$ and $100 \mathrm{~mJ})$ and Er: YAG laser $(0.5 \mathrm{w}$ and $50 \mathrm{~mJ}-1 \mathrm{w}$ and $100 \mathrm{~mJ})$. The canals were then infected with enterococcus faecalis. The rate of colony reduction in the irrigant group in both direct and curved canal was $100 \%$. This rate was $75.8 \%$ and $73 \%(\mathrm{p}>0.05)$ respectively in the Nd: YAG group (0.5 w and $50 \mathrm{~mJ}), 88.2$ and $84.5 \%$ $(\mathrm{p}>0.05)$ respectively in the Nd: YAG group (1 w and $100 \mathrm{~mJ})$, 86.6 and $76.1 \%(\mathrm{p}<0.05)$ respectively in the Er: YAG group $(0.5$ $\mathrm{w}$ and $50 \mathrm{~mJ})$ and 94.6 and $86 \%(\mathrm{p}<0.05)$ in the Er: YAG group (1 w and $100 \mathrm{~mJ})$. Nd: YAG laser irradiation did not make a significant difference between the direct and curved groups, but the bactericidal effect of Er: YAG in the curved group was significantly lower than the direct group. Although the results of Er: YAG were slightly better than Nd: YAG, the difference between them was not significant [27]. 
Ballout et al. divided 50 maxillary incisors infected with Enterococcus faecalis into five groups: negative control, plasma jet, dielectric barrier discharge, PDT (660 nm diode laser) and positive control group ( $\mathrm{NaOCl}$ and ultrasound stimulation). In the apical and coronal regions, the colony count in the plasma and photodynamic therapy groups were similar to the negative control group and did not differ significantly. Also, photodynamic therapy showed a less significant effect than the plasma jet group. Only $\mathrm{NaOCl}$ had the best colony reduction and was able to reduce it to some extent [32].

Sabino et al. investigated the fungicidal effect of PDT $(660 \mathrm{~nm}$ diode laser) using methylene blue in the canals with a curvature of $15-25^{\circ}$. The canals were prepared with a rotary instrument and then laser irradiation was done with two types of fibers (diffuser and the common type) for 2 minutes for each canal. Evaluation of Candida albicans colony reduction using luminescence and digital camera imaging showed that irradiation with diffuser fiber tip caused $3.5 \mathrm{log}$ and in the laser group with the common tip caused $2 \log$ further reduction of Candida colony compared to the control group. The diffuser tip was able to reach its maximum ideal fungicidal effect in less than two minutes, while the maximum laser effect with the conventional tip at the end of six minutes of irradiation showed a relative fungicidal effect [30].

Moon et al. Evaluated the effect of irrigants activation with $\mathrm{Nd}$ : YAG laser on Gutta-percha sealing. 63 molar teeth with canal curvature of more than 20 degrees were selected and prepared by rotary instrument and divided into four groups of $17 \%$ EDTA and $5.25 \% \mathrm{NaOCl}$ with and without laser irradiation. The canals were then closed with Gutta-percha and fluorescent sealer. At 2 and 5 $\mathrm{mm}$ sections from the apex, the $17 \%$ EDTA group without laser, the $5.25 \% \mathrm{NaOCl}$ group with laser, and the 17\% EDTA group with laser showed the highest sealer penetration into the tubules, respectively. Also, laser-stimulated $\mathrm{NaOCl}$ showed a significantly better penetration than $\mathrm{NaOCl}$ without laser radiation [28].

Gupta et al. evaluated the effect of Er: YAG and Nd: YAG laser on irritant activation on improving sealer penetration in curved canals. They used two newly introduced irritants, including Largal Ultra and BioPure MTAD. 140 human molars were divided in seven groups including BioPure MTAD (Er: YAG and Nd: YAG and irigant), Largal Ultra (Er: YAG and Nd: YAG and irigant) and negative control (without laser and without irigant). Canals were prepared with a rotary instrument. After contact with irrigants and laser irradiation, the canals were filled with fluorescently labeled gutta-percha and examined by CLSM. Compared to the negative control group, laser improved the sealer penetration into dentin tubules and Er: YAG irradiation and the use of BioPure MTAD had better results [33].

Abdelgawad investigated the effect of irritants activation by 980 $\mathrm{nm}$ diode laser irradiation on the gutta-percha compaction using gutta-core or single-cone instrument. 24 molar teeth with a canal curvature of more than $20^{\circ}$ were prepared by a rotary instrument. The teeth were then divided into two groups of activation of $15 \%$ EDTA and $2.5 \% \mathrm{NaOCl}$ with and without laser irradiation and each group was divided into two subgroups of $\mathrm{s}$ gutta-core or single-cone. By preparing sections from $2,4,6,8$ and $12 \mathrm{~mm}$ from the apex, the percentage of gutta-percha filled area (PGFA) and the percentage of sealer filled area (PSFA) were evaluated using a stereomicroscope. Their findings showed that irrigant activation had the highest amount of PGFA. Gutta-core and the laser activation group significantly produced the highest filling level and the lowest sealer consumption in 4-6-8 $\mathrm{mm}$ sections compared to other sections [31].

\section{Discussion}

The results of ten reviewed studies showed that the irradiation of Er: YAG, Nd: YAG Er, Cr: YSGG, and diode lasers in the curved canals of human extracted teeth is effective generally for the smear layer removal, antibacterial and antifungal ends, irritant activation, filler compaction and sealer penetration into the dental tubules, but it is not a suitable tool for the cutting and shaping of the curved canals. Also, the efficacy of laser radiation in the above studies was related to the severity of canal curvature, type of laser and radiation setting, laser fiber tip and irrigants.

High power lasers, like erbium lasers, has an important role in shaping straight canals and preparing the cavities by bone-cutting $[35,36]$. Laser irradiation in curved canals has limitations in achieving the proper working length compared to hand or rotary instruments because it requires a longer irradiation time and increases the likelihood of technical errors such as wedge and elbow formation, perforation, and laser fiber breakage [25, 26, 34]. The occurrence of laser technical errors in curved canals is caused by reasons such as cumulative radiation dose, intensity of canal curvature, the use of thicker fibers with less flexibility and flat fiber tips compared to conical tips $[25,26]$. In addition, the laser fiber does not provide the proper signal to the dentist as hand instruments, leading to hypo or hyper instrurmentation of the canal. It seems that the formation of canals with a curvature of more than 10 degrees by laser is not suitable, especially in the apical areas $[25,26]$. In these cases, the use of a rotary instrument to form the canal is a more appropriate method, and the combination of laser radiation with it to improve the smear layer removal, increases its advantage $[25,35]$. Air and water spray to reduce the temperature of radiation due to the possibility of air and water passing through the apical foramen and also damage to the apex structure are other challenges of laser to shape a curved canal. Therefore, radiation at a distance of $2-3 \mathrm{~mm}$ from the apical foramen should be considered to reduce the incidence of subsequent periapical problems due to laser [25].

In the reviewed studies, $\mathrm{NaOCl}$, EDTA and $\mathrm{H}_{2} \mathrm{O}_{2}$ were used as irrigants. The main role of an irritant is to remove debris and microorganisms during endodontic treatment, which is caused by chemical or mechanical effects. So far, various irrigants have been introduced for endodontic treatment. These include acids, chelators such as EDTA, and alkaline solutions such as $\mathrm{NaOCl}$. EDTA is more capable of harvesting inorganic matter in the smear layer and debris than organic matter, and its combination with NAOCL, which is more effective in harvesting the organic part of debris, improves its performance [38]. However, the combination of these two substances in the long run causes demineralization of the dentin [39] and also reduces the active chlorine content of $\mathrm{NaOCl}[40]$ The agitation of irigants for their better penetration into the canal, especially the apical areas, improves the removal of debris from the canal. Ultrasound and laser are effective tools for agitating irrigants over syringe needle irrigation [41, 42]. In the reviewed studies, the laser in the curved canals resulted in smear layer removal alone $[25,26,34]$ or through the agitation of 
the irrigants $[25,26,29,33]$. The effect of laser activation of the irrigants to remove the smear layer in curved canals seems to be similar to that of laser radiation on direct canals as found in two of the reviewed studies $[25,26]$, although its removal in the apical areas is still limited $[25,26,43,44]$.

Proper root canal obstruction is one of the main goals of root canal treatment. To this end, the main canal filler should have a uniform density in the apical to coronal. A sealer also creates a better seal by closing the remaining pores between the main filler and the canal wall. Sealers also play an antimicrobial role by penetrating dentin tubules in these areas but degenerate over time [45]. Gutta-percha is the most common canal filler. In curved canals, the density of the filler, especially in areas past the curvature to the apical area, regardless of the filling technique, may not be done properly $[46,47]$ and increase the likelihood of failure of endodontic treatment [48]. In three reviewed studies, activation of irrigants by Er: YAG, Nd: YAG, and $660 \mathrm{~nm}$ diode laser improved root canal sealing using gutta-percha and sealer $[28,31$, 33]. In a study by Moon et al. The best sealing was performed by EDTA without Er: YAG laser and $\mathrm{NaOCl}$ produced a poorer sealing without activation [28]. In the study of Gupta et al. Er: YAG and Nd: YAG laser irradiation provided better penetration for gutta-percha and sealer than for the control group [33]. Also, in the Abdelgawad study, $660 \mathrm{~nm}$ diode laser radiation reduced sealer consumption [31]. Better smear layer removal by creating micro-bubbles from the evaporation of irrigants and opening of the

tubules is one of the mechanisms involved in improving the canal obstruction with laser. Also, microbubbles may potentially facilitate filler movement to the apical area and its compaction [31]. In the study of Yasuda et al. [27] the antibacterial effect of Er: YAG laser decreased from $100 \%$ in the direct canal to about $85 \%$ in the curved canal and in the Nd: YAG laser group, the effect decreased from 88.2 to $84.5 \%$. [27]. In a study by Ballout et al., unlike $\mathrm{NaOCl}, 660 \mathrm{~nm}$ diode laser irradiation in the form of photodynamic therapy did not cause antibacterial effects [32]. Also, in the study of Sabino et al. $660 \mathrm{~nm}$ diode laser had antiCandida albicans effects [30]. As can be seen, the antimicrobial effect of the laser depends on the wavelength, radiation setting and microorganisms type, in a way that powers higher than $0.5 \mathrm{w}$ increase its effectiveness $[27,49]$. In the study of Kasić et al. Er, Cr: YSGG, Er: YAG and Nd: YAG, respectively, reduced enterococcus faecalis in the direct canal by $100 \%, 100 \%$ and $62.1 \%$ [50]. The $660 \mathrm{~nm}$ diode laser appears to have moderate effects against Enterococcus faecalis as the most common infectious pathogen in the root canal compared to some diode laser wavelengths such as 810 and 980 [49, 51].

One of the concerns of laser radiation during root canal treatment is the increase in dentin temperature and the possibility of damage to periodontal tissue. Increasing the temperature by water and air spray when working on the root canal with Er, Cr: YSGG, Er: YAG and Nd: YAG lasers as well as the diode laser is less than $10^{\circ}[24,52-55]$ that appears dose not to cause thermal damage. In addition, creating time intervals between laser radiations can cause fluctuating changes in temperature and better thermal control.

Finally, the results of this review study show that Er, Cr: YSGG, Er: YAG and Nd: YAG and diodes lasers are suitable as an ad- juant instrument for smear layer removal, reduction of bacterial and Candida albicans colony, infiltration and compaction of the main filler and the sealer in curved canals. This depends on the type of laser, radiation setting and canal curvature severity. Also, canal shaping with Er, Cr: YSGG laser is associated with complications such as hyper instrumentation and perforation and is not suitable for curved canals $>10^{\circ}$. The use of fiber with a conical tip and smaller diameter can be associated with better therapeutic results in this type of canals.

\section{References}

[1]. Siqueira JF Jr. Aetiology of root canal treatment failure: why well-treated teeth can fail. Int Endod J. 2001 Jan;34(1):1-10. PubMed PMID: 11307374 .

[2]. Haupt F, Meinel M, Gunawardana A, Hülsmann M. Effectiveness of different activated irrigation techniques on debris and smear layer removal from curved root canals: a SEM evaluation. Aust Endod J. 2020 Apr;46(1):40-46. PubMed PMID: 30907051.

[3]. Kosti E, Zinelis S, Molyvdas I, Lambrianidis T. Effect of root canal curvature on the failure incidence of ProFile rotary $\mathrm{Ni}$-Ti endodontic instruments. Int Endod J. 2011 Oct;44(10):917-25. PubMed PMID: 21658071.

[4]. Stadler LE, Wennberg A, Olgart L. Instrumentation of the curved root canal using filing or reaming technique--a clinical study of technical complications. Swed Dent J. 1986;10(1-2):37-43. PubMed PMID: 3458317.

[5]. Ansari I, Maria R. Managing curved canals. Contemp Clin Dent. 2012 Apr;3(2):237-41. PubMed PMID: 22919234.

[6]. Imura N, Pinheiro ET, Gomes BP, Zaia AA, Ferraz CC, Souza-Filho FJ. The outcome of endodontic treatment: a retrospective study of 2000 cases performed by a specialist. J Endod. 2007 Nov;33(11):1278-82. PubMed PMID: 17963946.

[7]. Martins JNR, Marques D, Silva EJNL, Caramês J, Mata A, Versiani MA Prevalence of C-shaped canal morphology using cone beam computed tomography - a systematic review with meta-analysis. Int Endod J. 2019 Nov;52(11):1556-1572. PubMed PMID: 31215045.

[8]. Estrela C, Bueno MR, Barletta FB, Guedes OA, Porto OC, Estrela CR, Pécora JD. Identification of Apical and Cervical Curvature Radius of $\mathrm{Hu}$ man Molars. Braz Dent J. 2015 Jul-Aug;26(4):351-6. PubMed PMID: 26312971.

[9]. Roy A, Astekar M, Bansal R, Gurtu A, Kumar M, Agarwal LK. Racial predilection of C-shaped canal configuration in the mandibular second molar. J Conserv Dent. 2019 Mar-Apr;22(2):133-138. PubMed PMID: 31142981.

[10]. Boijink D, Costa DD, Hoppe CB, Kopper PMP, Grecca FS. Apically Extruded Debris in Curved Root Canals Using the WaveOne Gold Reciprocating and Twisted File Adaptive Systems. J Endod. 2018 Aug;44(8):12891292. PubMed PMID: 29908692.

[11]. Zmener O, Pameijer CH, Alvarez Serrano S, Hernandez SR. Cleaning efficacy using two engine-driven systems versus manual instrumentation in curved root canals: a scanning electron microscopic study. J Endod. 2011 Sep;37(9):1279-82. PubMed PMID: 21846548.

[12]. Glossen CR, Haller RH, Dove SB, del Rio CE. A comparison of root canal preparations using $\mathrm{Ni}$-Ti hand, $\mathrm{Ni}$-Ti engine-driven, and K-Flex endodontic instruments. J Endod. 1995 Mar;21(3):146-51. PubMed PMID: 7561658.

[13]. Sonntag D, Delschen S, Stachniss V. Root-canal shaping with manual and rotary Ni-Ti files performed by students. Int Endod J. 2003 Nov;36(11):71523. PubMed PMID: 14641434.

[14]. Guelzow A, Stamm O, Martus P, Kielbassa AM. Comparative study of six rotary nickel-titanium systems and hand instrumentation for root canal preparation. Int Endod J. 2005 Oct;38(10):743-52. PubMed PMID: 16164689.

[15]. DiVito E, Peters OA, Olivi G. Effectiveness of the erbium:YAG laser and new design radial and stripped tips in removing the smear layer after root canal instrumentation. Lasers Med Sci. 2012 Mar;27(2):273-80. PubMed PMID: 21120568.

[16]. Samiei M, Pakdel SM, Rikhtegaran S, Shakoei S, Ebrahimpour D, Taghavi P. Scanning electron microscopy comparison of the cleaning efficacy of a root canal system by Nd:YAG laser and rotary instruments. Microsc Microanal. 2014 Aug;20(4):1240-5. PubMed PMID: 24887536.

[17]. Onay EO, Gogos C, Ungor M, Economides N, Lyssaris V, Ogus E, Lambrianidis T. Effect of Er,Cr:YSGG laser irradiation on apical sealing ability of calcium silicatecontaining endodontic materials in root-end cavities. Dent Mater J. 2014;33(4):570-5. PubMed PMID: 25087664.

[18]. Anagnostaki E, Mylona V, Parker S, Lynch E, Grootveld M. Systematic Review on the Role of Lasers in Endodontic Therapy: Valuable Adjunct 
Treatment? Dent J (Basel). 2020 Jul 1;8(3):63. PubMed PMID: 32630217.

[19]. Mohammadi Z. Laser applications in endodontics: an update review. Int Dent J. 2009 Feb;59(1):35-46. PubMed PMID: 19323310.

[20]. Walia V, Goswami M, Mishra S, Walia N, Sahay D. Comparative Evaluation of the Efficacy of Chlorhexidine, Sodium Hypochlorite, the Diode Laser and Saline in Reducing the Microbial Count in Primary Teeth Root Canals - An In Vivo Study. J Lasers Med Sci. 2019 Fall;10(4):268-274. PubMed PMID: 31875118.

[21]. Meire MA, Coenye T, Nelis HJ, De Moor RJ. Evaluation of Nd:YAG and Er:YAG irradiation, antibacterial photodynamic therapy and sodium hypochlorite treatment on Enterococcus faecalis biofilms. Int Endod J. 2012 May;45(5):482-91. PubMed PMID: 22243483.

[22]. Deleu E, Meire MA, De Moor RJ. Efficacy of laser-based irrigant activation methods in removing debris from simulated root canal irregularities. Lasers Med Sci. 2015 Feb;30(2):831-5. PubMed PMID: 24091791.

[23]. Olivi G. Laser Use in Endodontics: Evolution from Direct Laser Irradiation to Laser- Activated Irrigation. J Laser Dent J Laser Dent. 2013;2121(22):5871.

[24]. Guidotti R, Merigo E, Fornaini C, Rocca JP, Medioni E, Vescovi P. Er:YAG 2,940-nm laser fiber in endodontic treatment: a help in removing smear layer. Lasers Med Sci. 2014 Jan;29(1):69-75. PubMed PMID: 23212445.

[25]. Matsuoka E, Jayawardena JA, Matsumoto K. Morphological study of the Er,Cr:YSGG laser for root canal preparation in mandibular incisors with curved root canals. Photomed Laser Surg. 2005 Oct;23(5):480-4. PubMed PMID: 16262578 .

[26]. Jahan KM, Hossain M, Nakamura Y, Yoshishige Y, Kinoshita J, Matsumoto K. An assessment following root canal preparation by Er,Cr: YSGG laser irradiation in straight and curved roots, in vitro. Lasers Med Sci. 2006 Dec;21(4):229-34. PubMed PMID: 17072516.

[27]. Yasuda Y, Kawamorita T, Yamaguchi H, Saito T. Bactericidal effect of Nd:YAG and Er:YAG lasers in experimentally infected curved root canals. Photomed Laser Surg. 2010 Oct;28 Suppl 2:S75-8. PubMed PMID: 20738170.

[28]. Moon YM, Kim HC, Bae KS, Baek SH, Shon WJ, Lee W. Effect of laseractivated irrigation of 1320-nanometer Nd:YAG laser on sealer penetration in curved root canals. J Endod. 2012 Apr;38(4):531-5. PubMed PMID: 22414844.

[29]. Murugesan MS, Rajasekaran M, Indra R, Suganthan P. Efficacy of Er, Cr : YSGG Laser with Conical Tip Design in Smear Layer Removal at the Apical Third of Curved Root Canals. 2013;3(August):55-9.

[30]. Sabino CP, Garcez AS, Núnez SC, Ribeiro MS, Hamblin MR. Real-time evaluation of two light delivery systems for photodynamic disinfection of Candida albicans biofilm in curved root canals. Lasers Med Sci. 2015 Aug;30(6):1657-65. PubMed PMID: 25060900.

[31]. Abdelgawad L. QUALITY OF SINGLE CONE AND GUTTA CORE OBTURATION IN CURVED ROOT CANALS AFTER NEEDLE OR DIODE LASER IRRIGANT ACTIVATION USING CONE BEAM COMPUTED TOMOGRAPHY AND STEREOMICROSCOPE. Egypt Dent J. 2016;62(1):1211-20.

[32]. Ballout H, Hertel M, Doehring J, Kostka E, Hartwig S, Paris S, Preissner S. Effects of plasma jet, dielectric barrier discharge, photodynamic therapy and sodium hypochlorite on infected curved root canals. J Biophotonics. 2018 Mar;11(3). PubMed PMID: 29024574.

[33]. Gupta R, Wadhwani KK, Tikku AP, Chandra A. Effect of laser-activated irrigation on smear layer removal and sealer penetration: An in vitro study. J Conserv Dent. 2020 Sep-Oct;23(5):451-456. PubMed PMID: 33911352.

[34]. Nasher R, Hilgers RD, Gutknecht N. Debris and Smear Layer Removal in Curved Root Canals Using the Dual Wavelength Er,Cr:YSGG/Diode $940 \mathrm{~nm}$ Laser and the XP-Endoshaper and Finisher Technique. Photobiomodul Photomed Laser Surg. 2020 Mar;38(3):174-180. PubMed PMID: 31968180.

[35]. Kokuzawa C, Ebihara A, Watanabe S, Anjo T, Bolortuya G, Saegusa H, Suda H. Shaping of the root canal using Er:YAG laser irradiation. Photomed Laser Surg. 2012 Jul;30(7):367-73. PubMed PMID: 22690799.

[36]. Moogi PP, Rao RN. Cleaning and shaping the root canal with an Nd: YAG laser beam: A comparative study. J Conserv Dent. 2010 Apr;13(2):84-8.
PubMed PMID: 20859481.

[37]. Becker TD, Woollard GW. Endodontic irrigation. Vol. 49, General dentistry. 2001. p. 272-6.

[38]. Johal S, Baumgartner JC, Marshall JG. Comparison of the antimicrobial efficacy of $1.3 \% \mathrm{NaOCl} / \mathrm{BioPure}$ MTAD to $5.25 \% \mathrm{NaOCl} / 15 \%$ EDTA for root canal irrigation. J Endod. 2007 Jan;33(1):48-51. PubMed PMID: 17185130

[39]. Ozdemir HO, Buzoglu HD, Calt S, Cehreli ZC, Varol E, Temel A. Chemi$\mathrm{cal}$ and ultramorphologic effects of ethylenediaminetetraacetic acid and sodium hypochlorite in young and old root canal dentin. J Endod. 2012 Feb;38(2):204-8. PubMed PMID: 22244637.

[40]. Rossi-Fedele G, Doğramaci EJ, Guastalli AR, Steier L, de Figueiredo JA. Antagonistic interactions between sodium hypochlorite, chlorhexidine, EDTA, and citric acid. J Endod. 2012 Apr;38(4):426-31. PubMed PMID: 22414823.

[41]. Rodrigues CT, Duarte MAH, Guimarães BM, Vivan RR, Bernardineli N. Comparison of two methods of irrigant agitation in the removal of residual filling material in retreatment. Braz Oral Res. 2017 Dec 18;31:e113. PubMed PMID: 29267674.

[42]. Gu LS, Kim JR, Ling J, Choi KK, Pashley DH, Tay FR. Review of contemporary irrigant agitation techniques and devices. J Endod. 2009 Jun;35(6):791-804. PubMed PMID: 19482174.

[43]. da Costa Lima GA, Aguiar CM, Câmara AC, Alves LC, Dos Santos FA, do Nascimento AE. Comparison of smear layer removal using the Nd:YAG laser, ultrasound, ProTaper Universal system, and CanalBrush methods: an in vitro study. J Endod. 2015 Mar;41(3):400-4. PubMed PMID: 25600669.

[44]. Akyuz Ekim SN, Erdemir A. Comparison of different irrigation activation techniques on smear layer removal: an in vitro study. Microsc Res Tech. 2015 Mar;78(3):230-9. PubMed PMID: 25582378.

[45]. Komabayashi T, Colmenar D, Cvach N, Bhat A, Primus C, Imai Y. Comprehensive review of current endodontic sealers. Dent Mater J. 2020 Sep 29;39(5):703-720. PubMed PMID: 32213767.

[46]. Kersten HW, Fransman R, Thoden van Velzen SK. Thermomechanical compaction of gutta-percha. II. A comparison with lateral condensation in curved root canals. Int Endod J. 1986 May;19(3):134-40. PubMed PMID: 3460968.

[47]. Sobhi MB, Khan I. Penetration depth of nickel titanium and stainless steel finger spreaders in curved root canals. J Coll Physicians Surg Pak. 2003 Feb;13(2):70-2. PubMed PMID: 12685945.

[48]. Wu MK, Kast'áková A, Wesselink PR. Quality of cold and warm guttapercha fillings in oval canals in mandibular premolars. Int Endod J. 2001 Sep;34(6):485-91. PubMed PMID: 11556517.

[49]. Gutknecht N, Franzen R, Schippers M, Lampert F. Bactericidal effect of a 980-nm diode laser in the root canal wall dentin of bovine teeth. J Clin Laser Med Surg. 2004 Feb;22(1):9-13. PubMed PMID: 15117481.

[50]. Kasić S, Knezović M, Beader N, Gabrić D, Malčić AI, Baraba A. Efficacy of Three Different Lasers on Eradication of Enterococcus faecalis and Candida albicans Biofilms in Root Canal System. Photomed Laser Surg. 2017 Jul;35(7):372-377. PubMed PMID: 28426292.

[51]. Sarda RA, Shetty RM, Tamrakar A, Shetty SY. Antimicrobial efficacy of photodynamic therapy, diode laser, and sodium hypochlorite and their combinations on endodontic pathogens. Photodiagnosis Photodyn Ther. 2019 Dec;28:265-272. PubMed PMID: 31585175.

[52]. Kimura Y, Yonaga K, Yokoyama K, Kinoshita J, Ogata Y, Matsumoto K. Root surface temperature increase during Er:YAG laser irradiation of root canals. J Endod. 2002 Feb;28(2):76-8. PubMed PMID: 11833692.

[53]. Kobayashi K, Yamazaki Y, Tomita T, Tsuchida M, Ozawa T, Kohno A, et al. Temperature elevation on root surfaces during Nd:YAG laser irradiation in root canals. Int Congr Ser. 2003;1248(C):287-92.

[54]. da Costa Ribeiro A, Nogueira GE, Antoniazzi JH, Moritz A, Zezell DM. Effects of diode laser $(810 \mathrm{~nm})$ irradiation on root canal walls: thermographic and morphological studies. J Endod. 2007 Mar;33(3):252-5. PubMed PMID: 17320707

[55]. Al-Zand S, Al-Maliky M, Mahmood A, Al-Karadaghy T. Temperature elevation investigations on the external root surface during irradiation with 940 $\mathrm{nm}$ diode laser in root canal treatment. Saudi Endod J. 2018;8(1):14-8. 